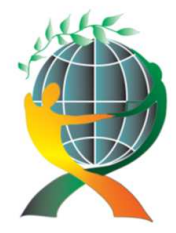

\author{
(online) = ISSN $2285-3642$ \\ ISSN-L = $2285-3642$ \\ Journal of Economic Development, Environment and People \\ Volume 7, Issue 2, 2018
}

URL: http://jedep.spiruharet.ro

e-mail: office jedep@spiruharet.ro

\title{
INTERNET AS MEDIA LITERATURE "KNOWLEDGE OF ISLAMIC HISTORY": Case Study Students In Jakarta, Indonesia
}

\author{
Syamsuri Ali $^{1}$, Budi Satria ${ }^{2}$ \\ ${ }^{1}$ Fakultas Tarbiyah dan Keguruan, Universitas Negri Islam Raden Inten, Lampung, Indonesia \\ ${ }^{2}$ Fakultas Teknik dan MIPA, Universitas Indraprasta PGRI, Jakarta, Indonesia
}

\begin{abstract}
The Internet has a huge impact on human life, especially students. Open access to information, will improve the process of disseminating knowledge. This study aims to analyze the level of effectiveness of the use of internet media in increasing the knowledge of students in Jakarta on the history of Islam. The study involved 150 respondents categorized by their administrative region; South Jakarta, East Jakarta, West Jakarta, North Jakarta and Central Jakarta. The results of the study were processed descriptively. Variable in the research are; the attitude of internet users, subjective norms, interest in learning and learning behavior. The results showed that the use of the Internet as a media of literacy is currently not optimal. One of the reasons is, the limitations of internet links that discuss the history of Islamic knowledge in the form of scientific studies, mostly just a blog that is less the sense of scientific, so that students prefer to find sources of literacy from the library (printed book)
\end{abstract}

Keywords: Literacy media, Internet, Knowledge of Islamic History, Jakarta

\section{JEL Codes: 129}

How to cite: SATRIA, B., \& ALI, S. (2018). Internet as Media Literature "Knowlwdge of Islamic History": Case Study Students In Jakarta, Indonesia. Journal of Economic Development, Environment and People, 7(2), 3036. doi: http://dx.doi.org/10.26458/jedep.v7i2.582

\section{Introduction}

The Internet becomes a medium of information sources that were difficult to access. Library is one of the most expensive source of information, considering that access to the internet is still very difficult for people in some areas. Internet media, enabling a person in Indonesia to access libraries at universities at home and abroad (digital liberary) and obtain information indefinitely.

Today millions of people throughout the world are using the Internet (Ahadzadeh, 2017). Internet access users continue to increase, in line with the development of communication technology. Overall e-Marketer predicts the number of internet users in the world reached 3.8 billion in 2018. While in Indonesia the netter population reached 112 million people by 2017 (http://tekno.kompas.com/read/ 2014/11/24/743008 ), making Indonesia as the 6th country with the most Internet users in the World, where Indonesia has the top five countries in the internet users in sequence; China, America, United States, India, Brazil and Japan (www.emarketer.com). 


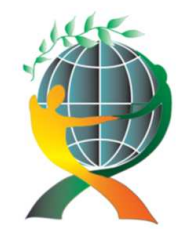

\author{
(online) $=$ ISSN $2285-3642$ \\ ISSN-L = $2285-3642$ \\ Journal of Economic Development, Environment and People \\ Volume 7, Issue 2, 2018 \\ URL: http://jedep.spiruharet.ro \\ e-mail: office jedep@spiruharet.ro
}

The Internet has a vital role in life in the current era of technology and information, the ease of access using extensive information technology through e-mail, chat and social networking sites. From some activities conducted by accessing the internet social networking site is the most popular sites, especially for teens. These sites include Facebook, Twitter, Path, Instagram, Waze, Ask.fm, Tumblr, Pinterest, Linkedln and Google+. Indonesia has 49 percent of the total population and has active use of social networks with more than 90 percent of them using mobile phones (Half of Indonesia's Active Population at Medsos http / www.Bisnis.com Accessed January 31, 2018. Duwi Setiya Ariyanti). It is unfortunate if the internet is only used to access social networking, while on the other hand many benefits that can be used one of them is as a medium of learning (Untari, 2014; Hamka, 2015; Kaliky, 2013; Schmar and Dobler, 2003; Dogruer et al, 2011). Social Network Sites (SNS) are among the most popular sites on the web. According to recent rankings from Alexa.com1 of the top 500 sites on the web, Facebook is ranked second from the top followed by YouTube in third place and Twitter in ninth places (Al-Saggraf, 2017)

Internet is one of media that can use by student to support their literacy. Energy literacy is multidimensional, comprising broad content knowledge as well as affect and behaviour (Chen et al, 2015) and the scientific literacy is considered as a benchmark of high and low quality of science education in a country (Rubini et al, 2016). With the internet media as a medium in learning in the world of education brings a change in teaching and learning process. There are at least five moves in the learning process, first from training to appearance, second from classroom to anytime and anywhere, third from paper to online, four physical facilities to network facilities, five from real time cycle time (Rosenberg, 2001 ). When the previous studies on the Internet as examined, the taught in the traditional (Benoit et al, 2006), thus governments should consider adjusting or reducing the proportion of inputs and outputs Peng et al, 2017), it's needed to stimulate the internet utilizing in educational field

Jakarta is the capital of the State of Indonesia, with a fairly complex function; as a business center, a center of government and a center for social and social activities, makes Jakarta one of the areas with high cultural and religious intetations (Untari et al., 2017). Based on Jakarta BPS data, more than 80 percent of Jakarta's population is Muslim. Many Islamic cultures adorn most of the history of development of tribes and regions in Indonesia, including Jakarta, where Betawi is a native tribe of Jakarta has a very close relationship with the development of Islamic history in the archipelago, this inimenjapan History of Islamic Development is one of the knowledge that must be understood by the generation young as the next generation.

Related to the great need of knowledge of the development of Islamic history in the young generation in Jakarta, and the role of internet in the life of Urban people such as DKI Jakarta especially students as a reflection of young scholars, it is important to examine further how high the level of ability of students in using internet as media literasi knowledge of Islamic history. The results of the study are expected to give an overview of the level of students' preferences in finding the source of literacy through the internet media.

\title{
2. Method
}

The research was conducted in five administrative areas of Jakarta; South Jakarta, East Jakarta, North Jakarta, West Jakarta and Central Jakarta. The respondent category is a Muslim student who resides in the five areas. The total sample size is 150 people (30 people per region). The results of the research will be processed descriptively, while the variables in the study are the attitude of Internet users, subjective norms, interest in learning and learning behavior (Ricoida and Pibriana, 2016). The oprationalization of each variable 


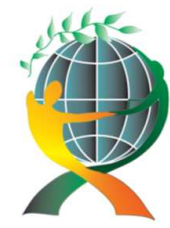

\author{
(online) $=$ ISSN $2285-3642$ \\ ISSN-L = $2285-3642$ \\ Journal of Economic Development, Environment and People \\ Volume 7, Issue 2, 2018
}

URL: http://jedep.spiruharet.ro

e-mail: office jedep@spiruharet.ro

is described in table 1. To determine whether the data is normally distributed using Kolmogorov-Smirnov and homogeneity test is used as a reference to determine the decision of statistical test by comparing the output of homogeneity processing with alpha value (5\%). Test of Conformity K Sample is done to compare the ability of students in using internet as inter-region literasi media.

Table 1. Oprational Variable

\begin{tabular}{|l|l|}
\hline Variable & Indicators \\
\hline Attitude & a) Interaction with internet and Online Transaction \\
& b) Information from the Internet and sharing Information on the Internet \\
c) Distraction / pleasure using the Internet \\
\hline d) Communication and friendship using the Internet \\
\hline a) Opinions on Referral information from the internet \\
b) Opinions about Sharing personal information on the Internet \\
c) Opinion about the fun that comes from the Internet \\
d) Opinions on the Security of Online transactions \\
e) Opinions about Friendship on the Internet \\
f) Opinions on Internet Information Responsibility \\
\hline & a) The desire to learn to use the Internet \\
b) Unsaturated learning by using the internet \\
c) Learn with material that can be accessed through the Internet \\
d) Internet is a must \\
e) Working on Tasks with the help of the Internet \\
f) Exchanging Information in Assignment \\
\hline a) Habits of following lessons and Repeating Lessons \\
b) Habit of Working Tasks and Visits to the library \\
c) Habits of learning and habits of learning difficulties \\
d) Habit of exams and reading textbooks \\
e) Use of the Internet in Learning
\end{tabular}

\title{
3. Result And Discusion
}

In contrast to the research developed during this time using the WebQual model, this research uses EPIC model where there are four dimensions in it namely; empathy, persuasion, impact and communication. The level of students ability to use internet as a literacy media explan of each category, it is presented in the following table 2:

Table 2. Level of category

\begin{tabular}{lll}
\hline & Range Score & Category \\
\hline $1,00-1,80$ & & Very ineffective \\
$1,81-2,60$ & Ineffective \\
$2,61-3,40$ & Average \\
$3,41-4.20$ & Effective \\
$2,20-5$ & Very effective \\
\hline
\end{tabular}

Source: Processed primary data, 2018 


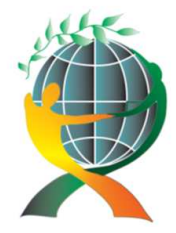

\author{
(online) $=$ ISSN $2285-3642$ \\ ISSN-L = $2285-3642$ \\ Journal of Economic Development, Environment and People \\ Volume 7, Issue 2, 2018 \\ URL: http://jedep.spiruharet.ro \\ e-mail: office jedep@spiruharet.ro
}

Based on the resulted questionnaire recapitulation distributed to 150 respondents at 5 administrative areas of Jakarta followed with the validity and reliability test, it is stated that all questionnaire question items are considered valid (with the significance level of $5 \%$ and $r$ table of 0.138 ) and reliable to be utilized as the research instrument. The results of validity and reliability test may be seen in table 3 below.

Table 3. Output Validity and Reliability Test

\begin{tabular}{|c|c|c|c|c|}
\hline Item & $\begin{array}{l}\text { Correected Item } \\
\text { Total Correlation }\end{array}$ & Infornation & Cronbach's Alpha & Information \\
\hline X1a & 0,838 & Valid & \multirow{4}{*}{$\begin{array}{r}\text { Attitude } \\
(0,617)\end{array}$} & \multirow{4}{*}{ High Reliability } \\
\hline $\mathrm{X} 1 \mathrm{~b}$ & 0,640 & Valid & & \\
\hline $\mathrm{X} 1 \mathrm{c}$ & 0,673 & Valid & & \\
\hline X1d & 0,702 & Valid & & \\
\hline $\mathrm{X} 2 \mathrm{a}$ & 0,320 & Valid & \multirow{6}{*}{$\begin{array}{c}\text { Sybjective norm } \\
(0,504)\end{array}$} & \multirow{6}{*}{ Average Reliability } \\
\hline$x 2 b$ & 0,474 & Valid & & \\
\hline $\mathrm{X} 2 \mathrm{c}$ & 0,378 & Valid & & \\
\hline$X 2 d$ & 0,381 & Valid & & \\
\hline $\mathrm{X} 2 \mathrm{e}$ & 0,561 & Valid & & \\
\hline X1f & 0,489 & Valid & & \\
\hline $\mathrm{X} 3 \mathrm{a}$ & 0,528 & Valid & \multirow{6}{*}{$\begin{array}{l}\text { Interest } \\
(0,498)\end{array}$} & \multirow{6}{*}{ Average Reliability } \\
\hline X3b & 0,472 & Valid & & \\
\hline X3c & 0,504 & Valid & & \\
\hline$x 3 d$ & 0,579 & Valid & & \\
\hline X3e & 0,411 & Valid & & \\
\hline X3f & 0,467 & Valid & & \\
\hline$\times 4 a$ & 0,685 & Valid & \multirow{5}{*}{$\begin{array}{c}\text { Behavior } \\
(0,663)\end{array}$} & \multirow{5}{*}{ High Reliability } \\
\hline$x 4 b$ & 0,670 & Valid & & \\
\hline $\mathrm{X} 4 \mathrm{c}$ & 0,711 & Valid & & \\
\hline$X 4 d$ & 0,598 & Valid & & \\
\hline $\mathrm{X} 4 \mathrm{e}$ & 0,609 & Valid & & \\
\hline
\end{tabular}

Source: Processed Primary data, 2018

Based on the results of the research instrument test, stated that all instruments are valid and reliable for use in research. Then the results of the questionnaire recapitulation of the respondents, subsequent data processing shows that there are differences in results are quite significant among several variables. The results of data sorting can be seen in table 4.

First, the researchers test the data normality and homogeneity test. To determine whether the data is normally distributed using Kolmogorov-Smirnov. By comparing the alpha value (5\%) with the significance value of the result of processing output. While homogeneity test is used as a reference to determine the decision of statistical test by comparing the output of homogeneity processing with alpha value (5\%). The output results show that the data is not normally distributed; on each respondent variable in each region is 0.000 <of alpha value $(0,05)$. Homogeneity test results also do not show different results. The results of data 


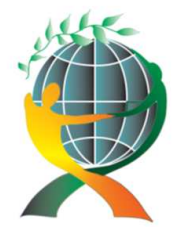

\author{
(online) $=$ ISSN $2285-3642$ \\ ISSN-L = $2285-3642$ \\ Journal of Economic Development, Environment and People \\ Volume 7, Issue 2, 2018
}

URL: http://jedep.spiruharet.ro

e-mail: office jedep@spiruharet.ro

recapitulation of all variables in each region has a 0.000 output result which means smaller when compared with alpha value 0.05 . So it can be interpreted that the data is heterogeneous. With the data not distributed normal and heterogeneous then the next statistical data processing using statistical methods NonParametrik.

Tabel 4. Datas Recapitulation

\begin{tabular}{|c|c|c|c|}
\hline Indicator & Variable & Score per indicator & Score per variable \\
\hline $\mathrm{X} 1 \mathrm{a}$ & \multirow[t]{4}{*}{ Attitude } & 3,4 & \multirow{4}{*}{3,52} \\
\hline $\mathrm{X} 1 \mathrm{~b}$ & & 3,6 & \\
\hline $\mathrm{X} 1 \mathrm{c}$ & & 3,9 & \\
\hline $\mathrm{X} 1 \mathrm{~d}$ & & 3,2 & \\
\hline$x 2 a$ & \multirow{6}{*}{ Subjektif norm } & 3,1 & \multirow{6}{*}{3} \\
\hline$x 2 b$ & & 3,4 & \\
\hline $\mathrm{X} 2 \mathrm{c}$ & & 2,8 & \\
\hline$x 2 d$ & & 2,7 & \\
\hline$x 2 \mathrm{e}$ & & 2,9 & \\
\hline$X 1 f$ & & 3,1 & \\
\hline X3a & \multirow{6}{*}{ Interest } & 2,8 & \multirow{6}{*}{2,98} \\
\hline$\times 3 b$ & & 3,3 & \\
\hline$x 3 c$ & & 2,9 & \\
\hline$X 3 d$ & & 2,7 & \\
\hline X3e & & 3,2 & \\
\hline$x 3 f$ & & 3,0 & \\
\hline $\mathrm{X} 4 \mathrm{a}$ & \multirow{5}{*}{ Behavior } & 2,7 & \multirow{5}{*}{2,75} \\
\hline$x 4 b$ & & 2,5 & \\
\hline $\mathrm{X} 4 \mathrm{c}$ & & 2,7 & \\
\hline$x 4 d$ & & 2,9 & \\
\hline $\mathrm{X} 4 \mathrm{e}$ & & 3,1 & \\
\hline
\end{tabular}

Source: Processed Primary data, 2018

Test of Conformity K Sample is done to compare the ability of students in using internet as inter-region literasi media. The result of data processing on media suitability test of $\mathrm{K}$ Sample, it is known that there is no difference of students ability in using internet as media of literacy between students in five areas of Jakarta (Asymp Sig .0115). This shows that in general the pattern of use and ability of students in DKI Jakarta in making the internet as a media literasi tend to be the same. Based on table 4 shows that the attitude variable internet users have the highest score (3.52). But the use of the internet is not able to give a significant impact in improving interest in learning and learning behavior. This is seen from the score of learning interest (2.98) and learning behavior (2.75) is quite small; where the indicator of "Habit of Working Tasks and Visits to the library" give the smallest score of variable "Behavior", it,s mean that nowadays the internet changed the student's habit of being lazy to search printed literature in the library, and it's related with Bucea et al (2017), that globalization is associated with an increased data to be prossesed from electronical processing and e- 


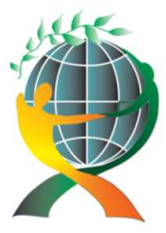

\author{
(online) = ISSN $2285-3642$ \\ ISSN-L = $2285-3642$ \\ Journal of Economic Development, Environment and People \\ Volume 7, Issue 2, 2018 \\ URL: http://jedep.spiruharet.ro \\ e-mail: office jedep@spiruharet.ro
}

information made it easy for human being in many ways (Tsuchiya et al, 2018). This is in line with previous research which states that 49 internet usage is used only to access social media (Half of Indonesia's Active Population at Medsos http / www.Bisnis.com Accessed January 31, 2018. Duwi Setiya Ariyanti).

\title{
4. Conclusion
}

The Internet is a medium that has been well known by the public in general, especially students. It's just based on research shows that current students are not maximal enough in using internet media as a media literasi especially knowledge of Islamic history. One of the reasons for the lack of interest of students in accessing the history of Islam through the internet is the lack of internet links that discusses the history of Islam in the form of scientific studies, most of them are less reliable blogs, so students prefer to find literacy sources from libraries ( printed book). The results of this study are expected to provide an overview for the writers and researchers of Islamic history to be able to further export and disseminate the results of research widely through the internet media. It is also expected that universities and related institutions to provide access for students to access e-library from overseas campus, so that students can more easily in obtaining information and scientific studies about the history of Islam.

E-learning method as one of the modern learning method can answer the gap that occurs in conventional learning method that has been applied. It's just that the problem arises when the motivation of students who less then make information technology to find ease in the learning process, so the use of the Internet as a medium of learning and literacy must be balanced with the strengthening of students' motivation and behavior in the use of the Internet in learning.

\section{References}

[1] Ahadzadeh, Ashraf Sadat. 2017. Online Health Information Seeking among Malaysian Women: Technology Acceptance Model Perspective. SEARCH. 9(1). P.47-70.

[2] Al-Saggaf, Yeslam. 2017. Information sharing on Facebook by Alone, Single and Lonely Female Users. SEARCH. 9(1). P.97-116.

[3] Benoit, P.J., Benoit,W.L., Milyp,J and Hansen,G.J. 2006. The effects of traditional versus web-assistence instruction on leraning and student satisfaction. University Of Missouri, Missouri.

[4] Bucea, Radu. Manea. Tonis. 2018. Deductive Systems For BigData Intergration. Journal of Ecinomic Development, Environment and People. 7(1). P. 49-54.

[5] Chen, Kuan-Li Chen. Chen, Po-Hsi Chen. Huang, Su-Han Huang. 2015. Using Contextualized Assessment to Measure the Energy Literacy of Middle and High School Students. Journal Of Reseach In Educational Science. 60(2). P.167-196. DOI: 10.6209/JORIES.2015.60(2).06

[6] Dogruer, Nazan. Eyyam, Ramadan. Menevis, Ipek. 2011. The Use Of Internet For Education Purposes. Procedia Sosial And Behavior Science.28(2011). P.606-611

[7] Hamka. 2015. Penggunaan Internet Sebagai Media Pembelajaran Pada Mahasiswa IAIN Palu. Jurnal Studi Islamika. 12(1). P.95-119

[8] Kaliky, Pahrul Idhani. 2013. Pemanfaatan Internet Dalam Pembelajaran Mahasiswa DI Universitas Pattimura, Ambon. Jurnal Komunikasi KAREBA. 2(1). P. 110-120. 


\author{
(online) $=$ ISSN $2285-3642$ \\ ISSN-L = $2285-3642$ \\ Journal of Economic Development, Environment and People \\ Volume 7, Issue 2, 2018 \\ URL: http://jedep.spiruharet.ro \\ e-mail: office jedep@spiruharet.ro
}

[9] Medyawati, Henny. Farida. Hegarini, Ega. 2012. Model Pengukuran Kualitas Layanan Website E-Banking di Indonesia. Seminar Nasional Aplikasi Teknologi Informasi . Jokjakrta

[10] Peng, Kai-Chiung . Chang, Chia-Wen . Li, Jui-Sheng . 2017. High School Students' Science Literacy and Educational Performance: A Comparison Between Taiwan and OECD Countries. Journal Of Research In Education Science. 62(4). P. 145-179. DOI:10.6209/JORIES.2017.62(4).06

[11] Rubini, B. Ardianto, D. Pursitasari, ID. Permana, I. 2016. Identify Scientific Literacy From The Science Teachers Perspective. Jurnal Pendidikan IPA Indonesia.5(2). P.229-303. DOI: 10.15294/jpii.v5i2.7689

[12] Roawnbwrg, Marc J. 2001. E-Learning: Strategies For Delivering Knowledge In The Digital Age. USA: McGraw-Hill Companies

[13] Ricoida, Desi Iba. Pibriana, Desi. 2016. Pengaruh Penggunaan Internet Terhadap Minat Dan Peilaku Belajar Mahasiswa . Seminar Nasional Sistem Informasi Indonesia. 1 Nopember 2016.

[14] Schmar, Elizabert. Dobler. 2003. Reading On the Internet; The link between literacy and technology. International Reading Association. P.80-85)

[15] Tsuchiya, A. Fraile, F. Koshijima, I. Ortiz, A. Poler, R. 2018. Software Define Network Firewell For Industry 4.0 Manufacturing Systems. Journal Of Industrial Engineering and Management. 11(2). P.318333.

[16] Untari, Dhian Tyas. Avenzora, Ricky. Darusman, Dudung. Prihatno, Joko. 2017. Betawi Culinary; SosialCultures Frame Of Multi Communities In Jakarta. Advance Science Letters. 23 (9). P.8519-8523

[17] Untari, Dhian Tyas. Avenzora, Ricky. Darusman, Dudung. Prihatno, Joko. 2017. Betawi Traditional Cuisines; Reflection the Native Culture of Jakarta (Formerly Known as Batavia). Journal of Economic Development Environment and People. 6(4). P. 64-76.

[18] Untari, Dhian Tyas. 2014. ECOPRENEURSHIP; Concept of Responsible Entrepreneurship. Malang: Prosiding $11^{\text {th }}$ International Annual Symposium on Management.

[19] Separuh Populasi Indonesia Aktif di Medsos. http/www.Bisnis.com. Diakses 31 Januari 2018. Duwi Setiya Ariyanti

[20] http://tekno.kompas.com/read/2014/11/24/0743008

[21] www.emarketer.com

[22] www.bpsjakarta.go.id 